\title{
Identifying Retrofitting Strategies to Achieve Energy Efficient Building Design in Existing Buildings
}

\author{
Fadi Salah, Merve Tuna Kayılı \\ ${ }^{1}$ Department of Architecture, Institute of Graduate Studies, Karabük University, Kastamonu Yolu Demir Çelik kampüsü, \\ 78050 Kılavuzlar, Karabük, Turkey \\ 2 Department of Architecture, Faculty of Architecture, Karabük University, Kastamonu Yolu Demir Çelik kampüsü, \\ 78050 Kılavuzlar, Karabük, Turkey \\ *Corresponding author, e-mail: mervetunakayili@karabuk.edu.tr
}

Received: 22 July 2020, Accepted: 29 September 2021, Published online: 04 November 2021

\begin{abstract}
Reducing the energy needs of existing buildings has a significant place in reducing global energy demands. High energy savings can be achieved with passive renovation suggestions in existing buildings. In this study, the effect of the proposed renovations for an educational structure in Safranbolu on the heating and cooling demands of the building was determined with a simulation program. Energy improvements of up to 70 percent have been achieved through passive improvement designs in orientation and insulation material. The highest energy saving (69.31\%) was realized through a scenario of rearranging spaces from the north side to the south side where the number of users is relatively high and selecting a $20 \mathrm{~cm}$ aerogel thermal insulation material. While the heating and cooling load, in accordance with the definition of a zero-energy building, could not be reached in this scenario, the study showed the importance of holistic decisions taken in the design phase of the building with respect to energy-efficient building design.
\end{abstract}

Keywords

energy efficiency building design, building information modelling (BIM), net zero energy building (NZEB), rock wool, aerogel panels

\section{Introduction}

Today, the vast majority of buildings are not designed to function in harmony with the environment they are in; consequently, the increased need for energy and that this demand is not obtained from renewable sources disrupts ecological balances and increases environmental pollution.

The main factors affecting heating and cooling loads required to provide thermal comfort conditions in buildings are design parameters, such as the location of the building, the location of the building relative to other buildings, the direction of the building according to the sun and the dominant wind directions, the building's form, and the optical and thermophysical properties of the building envelope.

The building envelope is the principal element controlling energy losses in buildings as the walls are the interface between the building and the outer environment. For this reason, the building envelope is the first step in reducing energy losses and needs and the primary building element that can be developed within the scope of the architectural discipline. In the following stages, architectural planning and material selections are implemented.
Retrofitting existing buildings for energy efficiency is especially important in reducing the energy use of building stock. The maximum energy efficiency is realized by the correct design and orientation during the building's design phase and selecting appropriate materials to be used in the shell. However, the existing building stock, which was not designed with energy efficiency considerations during the design phase, is also indispensable. Therefore, energy-efficient retrofitting of the existing building stock is as important as the energy-efficient design of the structure.

Retrofitting old buildings (or not old but whose thermal performance is insufficient) is essential in decreasing energy consumption and improving indoor comfort. The first step towards the goal of achieving Net Zero Energy Buildings (NZEBs) has been the reduction of the energy demand through increasing the thermal resistance in the walls and roof, and the use of high-performance glazing in windows for thermal insulation is commonly considered the primary energy efficiency measure taken in most buildings (Martinez, 2017; Moreno et al., 2019). Once the decision 
for retrofitting is taken, thermal insulation is a robust solution as it increases the overall thermal resistance of the building envelope (Martinez, 2017). Many of the traditional insulation materials, such as polyisocyanurate (PIR) or polyurethane (PUR), can provide adequate performance levels; however, the use of these materials to achieve the required retrofit performance results in significant loss of internal room space (Carty, 2017). Vatin et al. (2019) compared the thermal insulation characteristics of PIR, mineral wool, carbon fiber and aerogel, conducting experiments to determine the thermal conductivity of these materials. As a result, carbon fibers and aerogel panels were identified as having the lowest thermal conductivity. This result can be important for manufacturers of materials, building owners and building designers when choosing suitable insulation materials and correctly predicting the thermal and energy performance of the buildings and their energy efficiency (Vatin et al., 2019).

Improving the building envelopes requires a very thick insulation application. However, new and innovative thermal insulation can perform with relatively less insulation depth (Filate, 2014). Berardi, 2017, determined that aerogel blankets are already showing their effectiveness in retrofitting projects, while the development and adoption of aerogel enhanced rendering and aerogel incorporating glazing systems is progressively being used (Berardi, 2017). Berardi (2018) carried out a successive study to investigate the benefits of using aerogel-enhanced systems for the retrofitting project of an educational building as a case study. The study was based on a reliable model of the building and showed that significant energy savings could be achieved but with a high initial cost due to the uncompetitive pricing of aerogel. While assessing a building retrofit intervention towards the NZEB target, life cycle costing matrices should be considered, more than simple payback time (Berardi, 2018; Giuseppe et al., 2017).

Filate (2014) conducted a building simulation study into an energy refurbishment concept for an office building using nanogel / aerogel insulation plaster and new windows. The results showed that using $5 \mathrm{~cm}$ thick aerogel insulation boards could improve heat loss through external walls by $71 \%$. The same results can be obtained by using $11.5 \mathrm{~cm}$ and $7.6 \mathrm{~cm}$ thick mineral wool and rigid PUR / PIR insulation boards, respectively. It was also found that a combined retrofitting of only the walls and windows results in a $26 \%$ reduction in total energy loss, including a $38 \%$ reduction in base space heating demand; replacing the single glazed windows by air-filled double glazed insulating cuts the energy lost through the windows by $53 \%$ (Filate, 2014).
Sadeghifam et al. (2016) investigated the results of cooling loads of wall material retrofitting in countries with a tropical climate using Building Information Modeling (BIM) tools. The research used a public building as a case study in a hot region climate. The methodology of the research was based on the comparison of alternative physical specifications of wall components. Eight types of wall constructions were assessed. The results show that BIM applications, due to its parametric design ability, can effectively help in optimizing wall construction types in tropical climate areas before the construction phase .

Moreno et al. (2019) examined the validation of the energy balance between comfort in net-zero energy buildings through building energy simulation using BIM tools. Their methodology depended firstly on reducing the energy demands through increasing the thermal resistance in walls and roofs by using high-performance glazing in windows. Other steps were conducted to achieve the goal of NZEB, such as thermal and photovoltaic solar panels. The results show that air infiltration into the building and properties of the glazing system are the main factors affecting energy performance. The use of a low $U$ value envelope, triple glazing and external shading systems minimizes cooling loads (Moreno et al., 2019).

Ozarisoy and Altan 2019 carried out research to determine low energy design strategies for retrofitting an existing residential complex in Cyprus. The study focused on the energy performance of the existing residential buildings before and after the retrofitting phase as base scenario models. The researchers used BIM applications to carry out their work. The Autodesk Revit 2017 plug-in Green Building Studio energy performance analysis software was used for simulation. Some limited scenarios were evaluated, such as PV models and a ventilated façade. Energy site data were recorded and compared. The results of electricity, fuel and energy use of the prototype house at pre-retrofitting and post-retrofitting stages, showed a significant decrease in energy consumption through the life-cycle of the building (Ozarisoy and Altan, 2019).

Yang et al. (2019) studied aerogel glazing systems' thermal and daylight performances, conducted on a large atrium building project in a cooling dominant climate examining eight aerogel glazing samples. The results emphasized that the application of silica aerogel glazing can significantly reduce envelope total heat gain of a large-scale atrium building in a cooling dominant climate (Yang et al., 2019). Moreover, due to the excellent thermal performance, silica aerogel has a much higher selling price (75.24 US $\$ \mathrm{~m}^{2}$ ) 
than other standard insulation materials, resulting in a longer payback time (3.54 years) than other solutions $(0.22$ years for EPS and 0.07 years for XPS) (Yang et al., 2019). Experimental studies were carried out by Martinez (2017) examining the effect on building interiors of using super insulation materials for energy retrofitting of façades. The research showed the feasibility of using these materials in enhancing the building envelope. Martinez (2017) also concluded that using $0.015 \mathrm{~W} / \mathrm{mk}$ of service conditions could be projected to achieve highly insulated assemblies as low as $0.15 \mathrm{~W} / \mathrm{mk}$ with insulation thickness of approximately $10 \mathrm{~cm}$

A feasibility study of using silica aerogel as insulation for buildings was conducted by Huang (2012), using the life-cycle cost analysis method (LCCA). Silica Aerogel with the lowest thermal conductivity value of $0.0144 \mathrm{~W} / \mathrm{mk}$ was used. The results showed that the material used could help reduce the annual heat loss of a building by $50.90 \%$ and results in about half of the annual costs compared with other insulation types (Huang, 2012).

In addition to increasing the thermal conductivity resistance of the building envelope in retrofitting works, small arrangements that will not affect the facade setup can also have significant effects on interior design. The use of heating and lighting systems are two major factors that influence energy consumption in buildings (Mardookhy et al., 2014), both of which relate to building orientation. In arranging to boost solar gain, especially in cold seasons, it is imperative to accurately position a building to receive a substantial solar contribution (Carbonari et al., 2002; Wong and Fan, 2013). Pacheco et al. (2012) claim that enhancing building orientation and form can sustain energy savings of $36 \%$. Moreover, good orientation, location and landscape facilities may reduce energy consumptions by $20 \%$ (Spanos et al., 2005).

This study investigated possible energy-efficient renewal strategies in a training structure in Safranbolu, Turkey, through the scenarios established. The effect of the renewal strategies selected on the energy performance of the building was determined with a dynamic simulation program. The study is expected to shed light on the energy-efficient renovation of buildings in a cold climate zone.

\section{Materials and method}

\subsection{Materials}

In the study, a school located in Safranbolu was chosen to study energy retrofitting strategies in an existing building. Due to the large number of workshop classes in the building, a concentrated energy requirement was observed due to the devices used in the workshops.
As shown in Fig. 1, a case study was conducted on Safranbolu vocational high school, which is an educational public building located in Safranbolu city in Turkey at 41-degree 16-minute northern latitude, and 32-degree 41-minute eastern longitude. The building belongs to Karabük University and is a three-story building with surface area of $2300 \mathrm{~m}^{2}$. The basement, ground and first floors were considered the main floors of the building and are all represented in the case study of the research.

The ground floor contains the main lobby, other educational activities (classrooms), as well as the student affairs room and services rooms as shown in Fig. 2. The first floor contains computer laboratories, classrooms, administrative and academic offices at the south elevation, while the basement floor contains mainly storage areas, electrical room, bathrooms and some educational activities rooms (classrooms and a carpentry workshop).

The construction system of the building relies on a structural skeleton of columns, beams and slabs. Reinforced concrete can be considered as the main structural material of the building. However, the main structural material of exterior and interior walls is aerated concrete blocks. The construction type of the walls, roof and floors consist of the

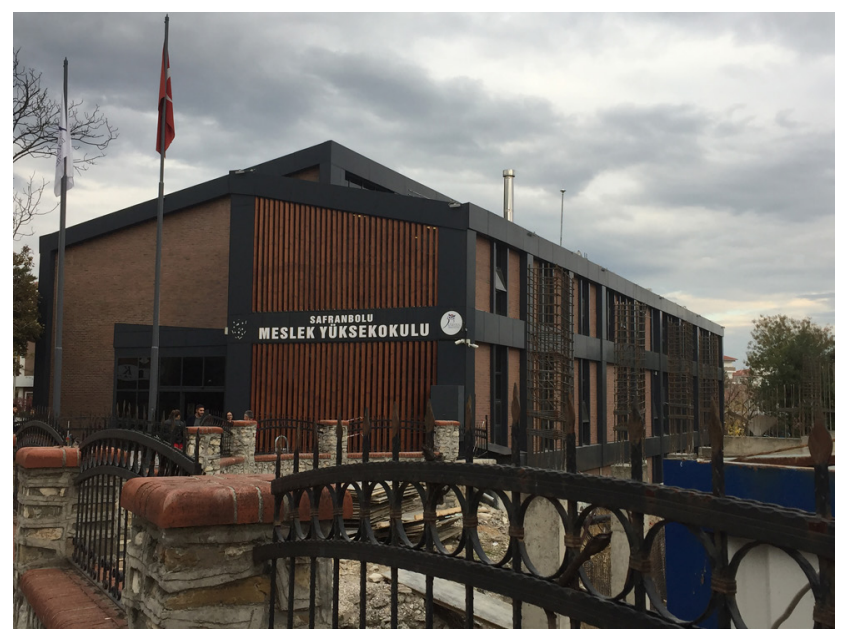

Fig. 1 Safranbolu Vocational High School Building

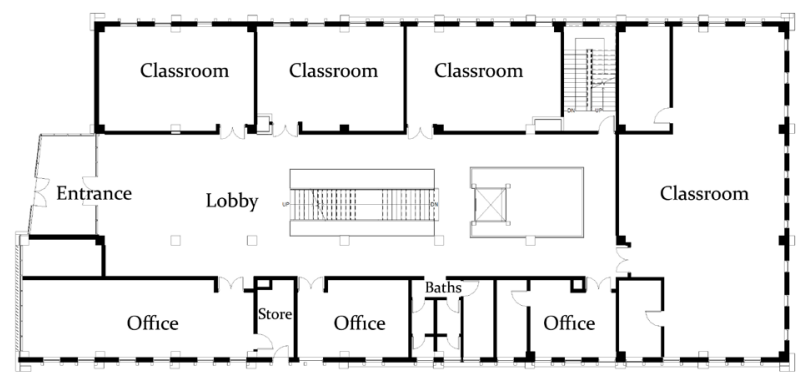

Fig. 2 Ground floor plan of the existing building 
traditional system of construction used in Turkey, and the insulation and coating are the most commonly used materials in Turkey in compliance with the Turkish standards of thermal insulation in buildings (Atmaca, 2008). The glazing type used is aluminium framed reflective glass. The main entrance of the building faces west. Table 1 shows the construction materials used in the building components with their thermal properties.

\subsection{Method}

In order to see the effect of energy-efficient retrofitting strategies in the selected building on the energy performance of the building, the selected case was modelled and simulated with a BIM application. A 3D BIM model of the original building and the scenarios were created with Revit Architecture BIM Software from imported CAD drawings and modelled in the software by parametric

Table 1 Thermal properties of construction materials

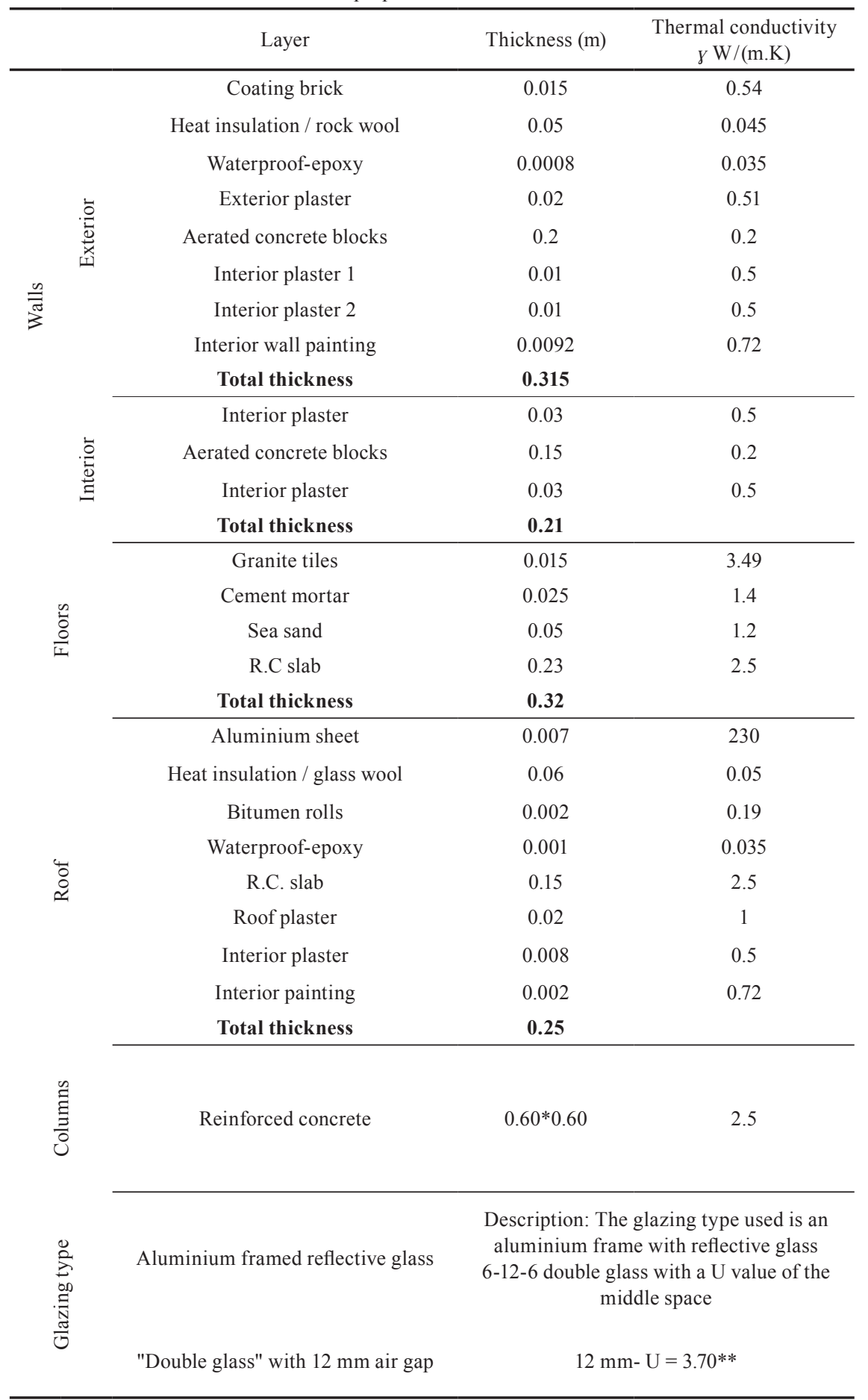

**TS 825 (Turkish standards of building insulation materials) (Atamca, 2008) 
design principles, taking into consideration the common thermal properties of materials in the Turkish standard booklet (Atmaca, 2008). In the second step, an energy analysis model of the base model and scenarios were prepared in Revit Architecture BIM Software and exported to the Green Building Studio (GBS). Consequently, the energy analytical models were simulated, and schedules of heating and cooling loads, conditions, spaces, types of rooms and spaces were prepared. Accordingly, the energy consumption was analyzed in a BIM application tool (GBS). In the final step, to optimize the energy usage of the case study, the results were analyzed and compared to the original existing building model's results.

In the study, some limited successive scenarios are assumed to examine the efficient energy modelling using BIM and to examine the possibility of reaching the NetZero-energy building concept (max. $15 \mathrm{kWh}$ for heating and cooling per square meter) through high-performance insulation material retrofitted to the exterior walls, roof and basement of the building. The scenarios are as follows.

\subsubsection{Mirroring the interior function}

This scenario assumes mirroring the interior function, in other words, moving the educational spaces and the most used functions facing the northern façade in the existing building, to face the southern façade as shown in Fig. 3, so that it may result in reducing the total heating and cooling demands to a lower value. The mirroring process was held to the three stories of the building as the most heated and cooled spaces were located on the northern side of the building.

\subsubsection{Thickness of heat insulation material}

This scenario involves changing the thickness of heat insulation material in the existing building components (external walls, basement and roof), which was rock wool, with a material that has a thermal conductivity $\gamma$ equal to $0.045 \mathrm{~W} / \mathrm{mK}$ from $5 \mathrm{~cm}$ to 20 and $40 \mathrm{~cm}$, respectively and then comparing the total heating and

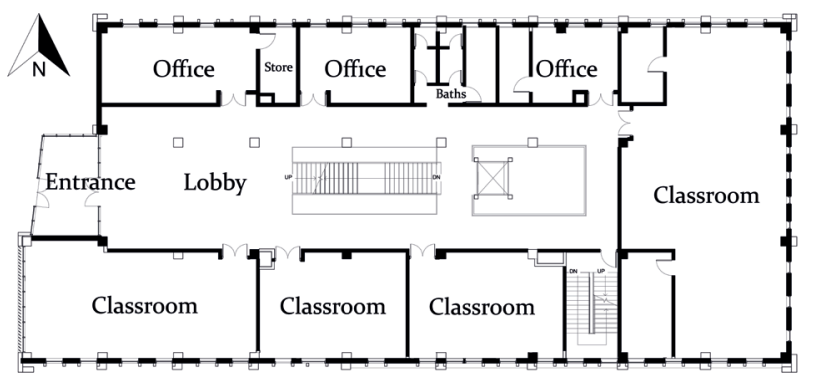

Fig. 3 First scenario of mirrored spaces of ground floor plan cooling demands for each case compared to the base model as shown in Fig. 4.

\subsubsection{Type and thickness of heat insulation material}

This scenario assumed changing the type of heat insulation material in the external walls, basement and roof construction. The existing heat insulation was $5 \mathrm{~cm}$ thick rock wool with thermal conductivity $y$ equal to $0.045 \mathrm{~W} / \mathrm{mK}$ according to the Turkish standards of building insulation materials (Atmaca, 2008). The new material is aerogel panel, which is a super high insulation material with thermal conductivity y equal to $0.013 \mathrm{~W} / \mathrm{mK}$ (Özçelik et al., 2017) with the same thickness as the base model $(5 \mathrm{~cm}), 10$ and $20 \mathrm{~cm}$ thicknesses in external walls, basement and roof construction.

\section{Results}

After the building was modelled, the energy simulation in Revit was conducted, as shown in Fig. 4. The models-base model and scenarios- were exported as a gXXML file format to the GBS and simulated by determining the location and weather station of the existing building. The results concentrated on the total annual heating and cooling demands of kilowatt-hours per meter squared in the following scenarios.

\subsection{Mirroring the interior functions}

The assumed strategy of mirroring the internal functions was designed and simulated. The 3D BIM model of the new scenario was prepared in the Revit Architecture BIM software by mirroring the spaces of the base model. Both models were then simulated on the GBS platform. The results showed that by mirroring the spaces, the total heating and cooling demand reduced from $61.68 \mathrm{kWh} / \mathrm{m}^{2}$ in the base model to $55.20 \mathrm{kWh} / \mathrm{m}^{2}$ in the suggested scenario, as shown in Fig. 5. The annual total heating and cooling demand were reduced by $10.51 \%$ by moving energy intensity spaces north to south. In addition, the heating load of the existing building was $52.26 \mathrm{kWh} / \mathrm{m}^{2}$, and the cooling load was $9.42 \mathrm{kWh} / \mathrm{m}^{2}$; with the internal functions mirrored, the heating and cooling load changed to 42.64 and $12.56 \mathrm{kWh} / \mathrm{m}^{2}$, respectively.

\subsection{Thickness of heat insulation material}

The assumed scenario of heat insulation thicknesses of the existing material (rock wool) was prepared in separate models in the Revit Architecture BIM Software and simulated on the GBS platform. 20 and $40 \mathrm{~cm}$ thicknesses were applied to the models separately. The results were then compared to those of the base model. The results show that 


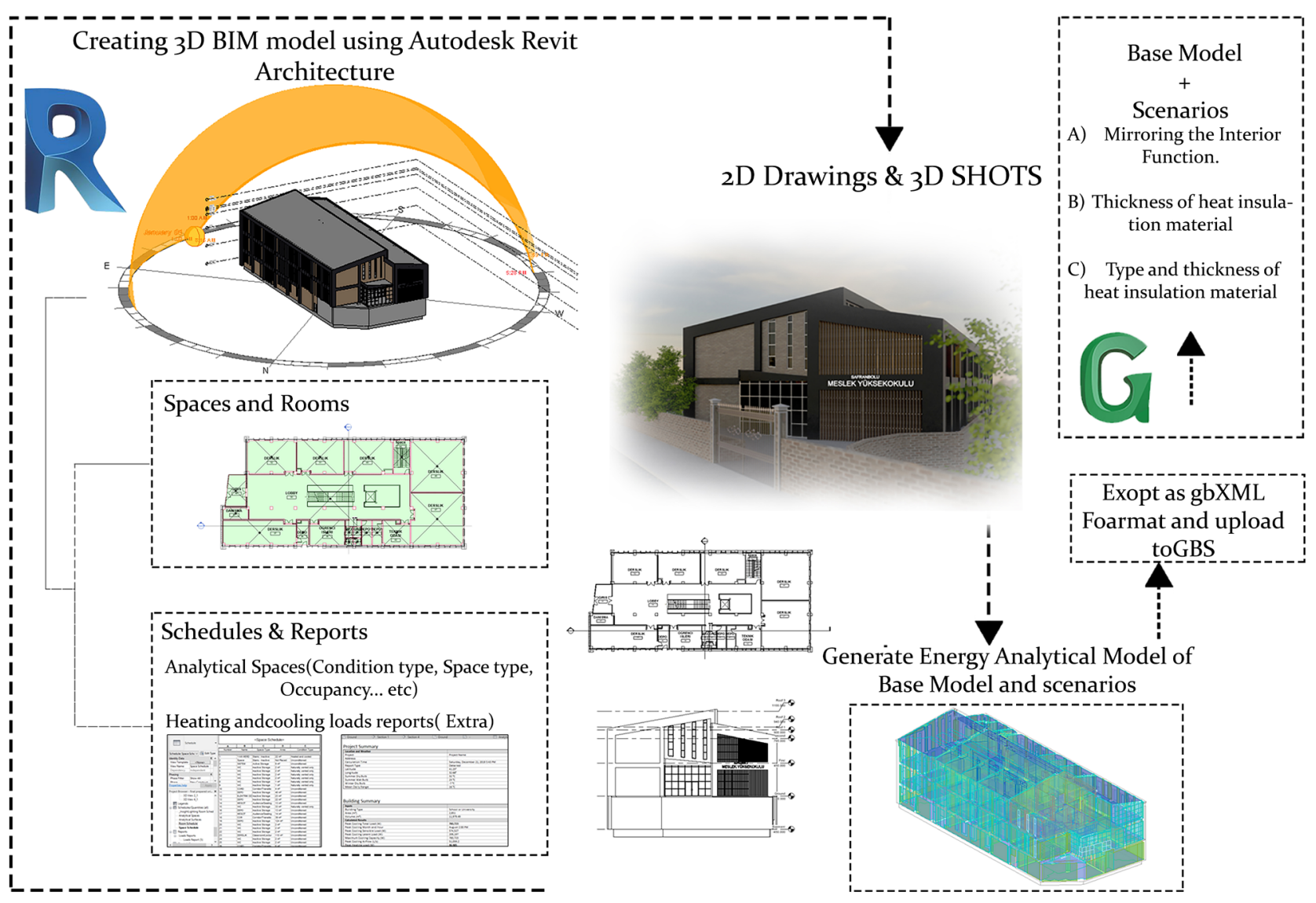

Fig. 4 Workflow

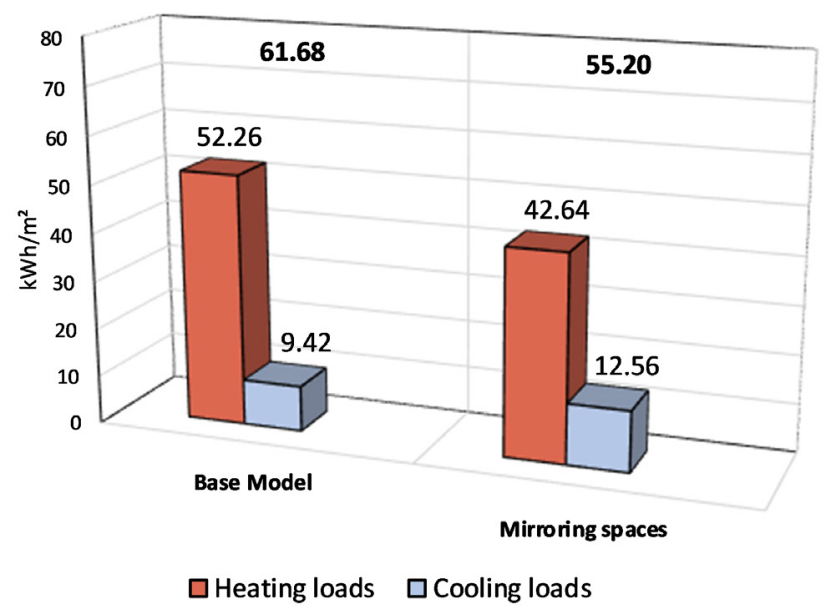

Fig. 5 The results of mirroring the interior energy intensity spaces

changing the thickness of rock wool insulation material from $5 \mathrm{~cm}$ in base model to 20 and $40 \mathrm{~cm}$ reduced the total heating and cooling demands from $61.68 \mathrm{kWh} / \mathrm{m}^{2}$ to 51.26 and $44.40 \mathrm{kWh} / \mathrm{m}^{2}$, respectively, as shown in Fig. 6. Using 20 and $40 \mathrm{~cm}$ rock wool as insulation material in building components, the building's annual total heating and cooling demands were reduced by $16.89 \%$ and $28.01 \%$, respectively

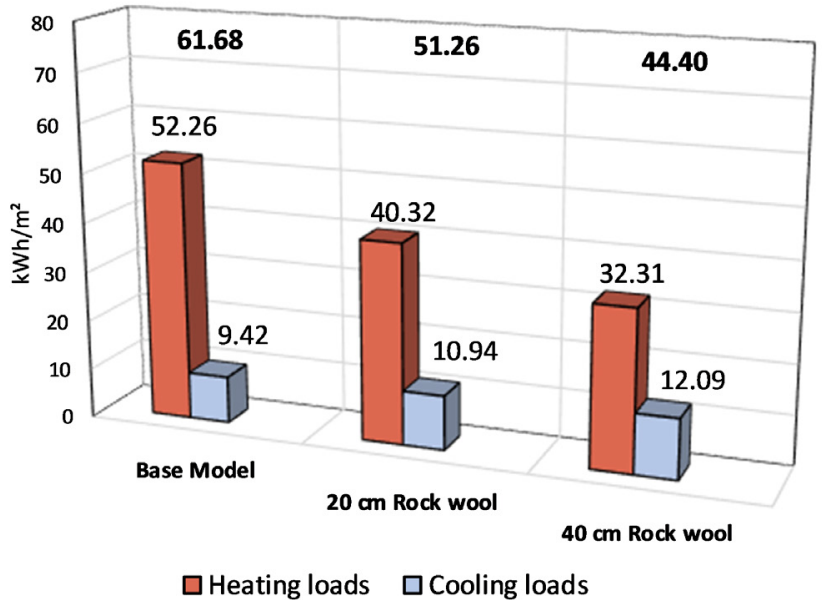

Fig. 6 The results of increasing thicknesses of heat insulation

In addition, as shown in Fig. 6, the heating load of the existing building (rock wool $5 \mathrm{~cm}$ ) was $52.26 \mathrm{kWh} / \mathrm{m}^{2}$, and the cooling load was $9.42 \mathrm{kWh} / \mathrm{m}^{2}$. While the thickness of rock wool was changed to 20 and $40 \mathrm{~cm}$, the heating and cooling load changed to $40.32 \mathrm{kWh} / \mathrm{m}^{2}, 32.31 \mathrm{kWh} / \mathrm{m}^{2}$ and $10.94 \mathrm{kWh} / \mathrm{m}^{2}, 12.09 \mathrm{kWh} / \mathrm{m}^{2}$, respectively. 


\subsection{Type and thickness of heat insulation material}

The assumed strategy of varying heat insulation material type and thickness from rock wool to high-performance insulation material were designed, and both scenarios were simulated on the GBS platform. When the results were compared, they showed that by changing the heat insulation type from the existing (rock wool) in the base model to high-performance insulation material (aerogel panels) with the same thickness $(5 \mathrm{~cm})$ for both in the building components, the total heating and cooling demands will be reduced from $61.68 \mathrm{kWh} / \mathrm{m}^{2}$ to $31.14 \mathrm{kWh} / \mathrm{m}^{2}$ as shown in Fig. 7.

Furthermore, the results indicated a reduction of $49.51 \%$ in heating and cooling demands. Similar results were detected by Huang (2012) of reduction in annual heat loss of approximately $50.90 \%$ by using silica aerogel with thermal conductivity equal to $0.014 \mathrm{~W} / \mathrm{mK}$ as insulation material, thus reducing the annual cost of heating to about half (Huang, 2012).

Aerogel panels, which are a high-performance insulation material, have a $y$ value of $0.013 \mathrm{~W} / \mathrm{mK}$. The cost of this scenario will be extremely high and impractical, but the author is attempting to examine the possibility of aerogel to achieve NZEB. Fig. 8 shows the results compared to the base model with $5 \mathrm{~cm}$ rock wool and 10 and $20 \mathrm{~cm}$ aerogel panels. The results showed that changing the heat insulation thicknesses and type will reduce the total heating and cooling demands from $61.68 \mathrm{kWh} / \mathrm{m}^{2}$ in the base model to $26.83 \mathrm{kWh} / \mathrm{m}^{2}$ for $10 \mathrm{~cm}$ and $21.67 \mathrm{kWh} / \mathrm{m}^{2}$ for $20 \mathrm{~cm}$ aerogel panels.

\subsection{All scenarios}

In the study, retrofitting suggestions such as replacing important sections by mirroring, changing thicknesses and the type of insulation materials were presented, and these scenarios were examined separately in the simulation

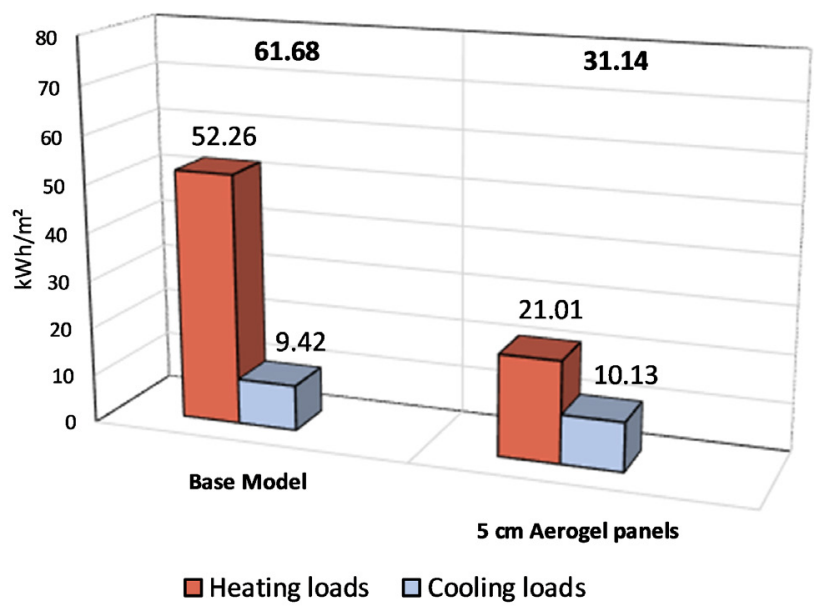

Fig. 7 The results of changing the type of heat insulation

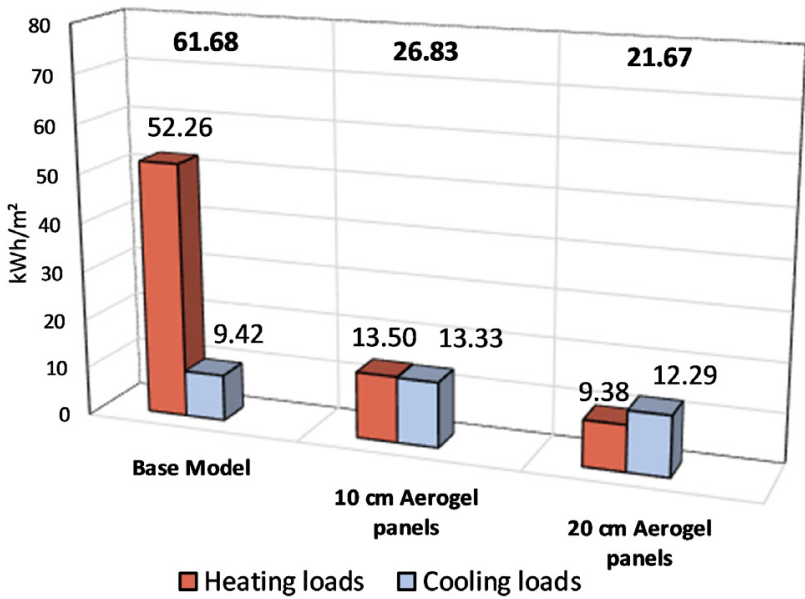

Fig. 8 The results of changing the type and thickness of heat insulation

program. The results were then compared to those that resulted from the base model simulation. When these suggestions are taken together, more effective outcomes can be obtained in reducing energy requirements. When the locations in the north are placed to the south, and by changing the thermal insulation material with $10 \mathrm{~cm}$ aerogel panels, the total heating and cooling demands will be reduced from $61.68 \mathrm{kWh} / \mathrm{m}^{2}$ to $22.75 \mathrm{kWh} / \mathrm{m}^{2}$, as shown in Fig. 9. Consequently, this is a $63.12 \%$ reduction in total heating and cooling energy consumption. Moreover, in addition to modifying the orientation of the voids, with the use of $20 \mathrm{~cm}$ aerogel, the total heating and cooling demands will be reduced from $61.68 \mathrm{kWh} / \mathrm{m}^{2}$ to $18.93 \mathrm{kWh} / \mathrm{m}^{2}$, which is a $69.31 \%$ reduction in energy consumption.

\section{Conclusion}

Using BIM simulation programs, the study analyzed various insulation material and design scenarios thought to reduce energy consumption due to heating and cooling loads, such as changing the orientation of spaces with small interventions, increasing the existing thermal insulation thicknesses and changing the type of thermal insulation material.

In summary, the data obtained demonstrate that:

- The transfer of spaces with a high number of users from the north to the south fronts resulted in a $10.51 \%$ reduction in the heating and cooling demand of the building under the cold climate conditions of Safranbolu, Turkey.

- While increasing the thickness of the $5 \mathrm{~cm}$ rock wool material in the existing structure to $20 \mathrm{~cm}$ and $40 \mathrm{~cm}$, the demand decreased by $16.89 \%$ and $28.01 \%$, respectively. 


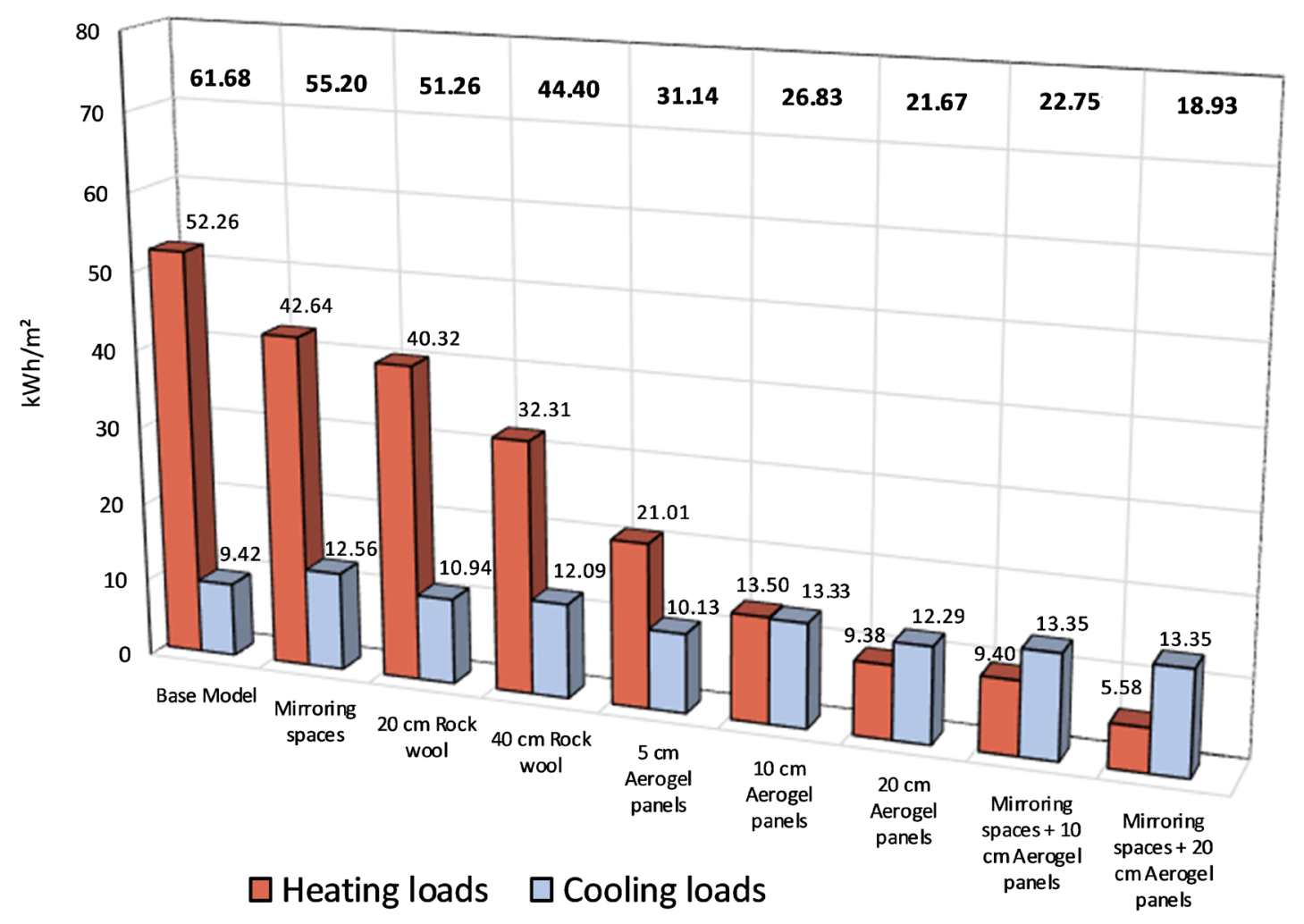

Fig. 9 The results of all scenarios

- When the $5 \mathrm{~cm}$ rock wool was replaced with $5 \mathrm{~cm}$ aerogel panels, which is a more innovative thermal insulation material, the heating and cooling demand decreased by $49.51 \%$.

- When the thickness of the aerogel panels was $10 \mathrm{~cm}$ and $20 \mathrm{~cm}$, the decrease in the demand for heating and cooling was $56.51 \%$ and $64.87 \%$, respectively.

- When the spaces with practical use in the north are placed to the south, and by changing the thermal insulation material with $10 \mathrm{~cm}$ aerogel panels, the decrease in the total heating and cooling demands was $63.12 \%$ and $69.31 \%$ for $20 \mathrm{~cm}$ aerogel panels.

- When data obtained through passive design applications, such as orientation and changing of insulation materials, types and thicknesses are examined, it can be concluded that heating and cooling demands can be reduced by up to $70 \%$. Nevertheless, there is still a long way to go in reaching net zero energy buildings. For existing buildings to reach the category of zero-energy buildings, they should be supported with both active and passive energy designs.

Furthermore, this study can also conclude that the most effective way to achieve a zero-energy building is through the design phase of the building.

The design phase, in which the structure's orientation, the insulation material used, and passive and active energy systems are planned, is critical. If the energy-efficient design criteria are ignored at this stage, severe problems, including cost, scaffolding, and building damage in the subsequent conversion of the building into an energy-efficient building. Therefore, in the design phase of the building, determining the energy efficient building design criteria, simulating the energy analysis and design scenarios of the building is vital.

Using BIM simulation software system can reduce both the number of building stock that needs to be retrofitted and their additional costs. 


\section{References}

Atmaca, U. (2008) "TS 825 Binalarda 1S1 yalıtım kuralları", (Thermal Insulation Requirements in Buildings), Turkish Standards Institution, Ankara, Turkey. (in Turkish)

Berardi, U. (2017) "The benefits of using aerogel-enhanced systems in building retrofits", Energy procedia, 134, pp. 626-635. https://doi.org/10.1016/j.egypro.2017.09.576

Berardi, U. (2018) "Aerogel-enhanced systems for building energy retrofits: Insights from a case study", Energy and Buildings, 159, pp. $370-381$. https://doi.org/10.1016/j.enbuild.2017.10.092

Carbonari, A., Rossi, G., Romagnoni, P. (2002) "Optimal orientation and automatic control of external shading devices in office buildings", Environmental Management and Health, 13(4), pp. 392-404. https://doi.org/10.1108/09566160210439305

Carty, L. (2017) "Analysis of the effects of aerogel insulation on the thermal performance of existing building envelopes", Master of science thesis, Edinburgh Napier University. Available at: http://researchrepository.napier.ac.uk/Output/1253724 [Accessed: 19 July 2020]

Filate, S. S. (2014) "Investigation of an energy refurbishment concept for office building using Nanogel ${ }^{\circledR}$ Aerogel insulation plaster and replaced windows by building simulation", Master of science thesis, Uppsala University. [online] Available at: https://www. diva-portal.org/smash/get/diva2:772909/ATTACHMENT01.pdf [Accessed: 10 July 2020]

Giuseppe, E. D., Iannaccone, M., Telloni, M., D’Orazio, M., Perna, C. D. (2017) "Probabilistic life cycle costing of existing buildings retrofit interventions towards nZE target: Methodology and application example", Energy and Buildings, 144, pp. 416-432. https://doi.org/10.1016/j.enbuild.2017.03.055

Huang, L. (2012) "Feasibility study of using silica aerogel as insulation for buildings", Master of Science thesis, KTH School of Industrial Engineering and Management, Available at: http://kth.diva-portal.org/ smash/get/diva2:533307/FULLTEXT01 [Accessed: 03 July 2020]

Mardookhy, M., Sawhney, R., Ji, S., Zhu, X., Zhou W. (2014) "A study of energy efficiency in residential buildings in Knoxville, Tennessee", Journal of Cleaner Production, 85, pp. 241-249. https://doi.org/10.1016/j.jclepro.2013.09.025

Martinez, R. G. (2017) "Highly Insulated Systems for Energy Retrofitting of Façades on its Interior", Procedia Environmental Sciences, 38, pp. 3-10. https://doi.org/10.1016/j.proenv.2017.03.065

Moreno, B., Gonzalo, F. D. A., Fernandez, J. A., Lauret, B., Hernandez, J. A. (2019) "A Building energy simulation methodology to validate energy balance and comfort in zero energy buildings", Journal of energy systems, 3(4), pp. 168-182. https://doi.org/10.30521/jes.623285
Ozarisoy, B., Altan, H. (2019) "Low-energy design strategies for retrofitting existing residential buildings in Cyprus", Proceedings of the Institution of Civil Engineers - Engineering Sustainability, 172(5), pp. 241-255. https://doi.org/10.1680/jensu.17.00061

Özçelik, M. Y., Soylu, S. K., Atmaca, İ. (2017) "Endüstriyel Bir Tesiste Aerojel ile Yalıtımın Teknik ve Ekonomik Analizi" (Technical and Economic Analysis of Insulation with Aerogel in an Industrial Facility), Presented at the 13th Ulusal Tesisat Mühendisliği Kongresi, İzmir, Turkey, April 19-22, 2017. (in Turkish)

Pacheco, R., Ordóñez, J., Martínez, G. (2012) "Energy efficient design of building: A review", Renewable and Sustainable Energy Reviews, 16(6), pp. 3559-3573. https://doi.org/10.1016/j.rser.2012.03.045

Sadeghifam, A. N., Marsono, A. K., Kiani, I., Isikdag, U., Bavafa, A. A., Tabatabaee, S. (2016) "Energy analysis of wall materials using building Information Modeling (BIM) of Public buildings in the tropical climate countries", Jurnal Teknologi, 78(10), pp. 35-41. https://doi.org/10.11113/jt.v78.7591

Spanos, I., Simons, M., Holmes, K. L. (2005) "Cost savings by application of passive solar heating", Structural Survey, 23(2), pp. 111-130. https://doi.org/10.1108/02630800510593684

Vatin, N., Sultanov, S., Krupina, A. (2019) "Comparison of Thermal Insulation Characteristics of PIR, Mineral Wool, Carbon Fiber, and Aerogel", In: Murgul, V., Pasetti, M. (eds.) International Scientific Conference Energy Management of Municipal Facilities and Sustanible Energy Technologies EMMFT 2018. Advances in Intelligent Systems and Computing, Springer International Publishing, Cham, Switzerland, pp. 877-883. https://doi.org/10.1007/978-3-030-19868-8_86

Wong, K., Fan, Q. (2013) "Building information modelling (BIM) for sustainable building design", Facilities, 31(3/4), pp. 138-157. https://doi.org/10.1108/02632771311299412

Yang, Y., Wu, H., Yang, L., Xu, T., Ding, Y., Fu, P. (2019) "Thermal and day-lighting performance of aerogel glazing system in large atrium building under cooling-dominant climates", Energy procedia, 158, pp. 6347-6357. https://doi.org/10.1016/j.egypro.2019.01.273 